The present paper has been published and must be quoted as follows:

Costa E., Goulart da Silva G., (2019), Non-Profit Accountability: the viewpoint of the primary stakeholders, Financial Accountability \& Management, 35, 37-54

Non-Profit Accountability: the viewpoint of the primary stakeholders

Ericka Costa (corresponding author)

University of Trento

Job title: Senior Lecturer of Accounting

Address: Via Inama, 5

38122 Trento - TN - Italy

Phone: +39 0461.282.322.

Fax +390461282.124

E-mail: ericka.costa@unitn.it

Geiza Goulart da Silva

EcoNomics, Inc

Job Title: Program Implementation Manager

Address: 24682 Del Prado Suite 230, Dana Point, CA, USA 92629

Phone: +1 9492784519

E.mail: geiza@economicsinc.net

Running title: Non-Profit Accountability 
Acknowledgements: The authors are extremely grateful to Giovanna Michelon (University of Exeter) and Teerooven Soobaroyen (University of Essex) for the constructive comments received in the early version of the paper.

Non-Profit Accountability: the viewpoint of the primary stakeholders

\begin{abstract}
By means of a questionnaire survey, this paper aims at analysing the primary stakeholder viewpoint regarding NPO accountability. In detail, it investigates the member's perspective regarding social accountability in a Cooperative Bank in Italy.

Our findings suggest that respondents had a high level of satisfaction with social reporting: a large portion of the sample indicated that they found social reporting to be useful, credible, transparent, and complete. Moreover, members of the cooperative bank under investigation consider social accountability as a way to improve relationships, strengthen trust among members, and demonstrate transparency in its activities within the community.
\end{abstract}

\title{
Keywords
}

NPO accountability, receiver perspective, primary stakeholder, social reporting, cooperative bank. 


\section{Non-Profit Accountability: the viewpoint of the primary stakeholders}

\section{Introduction}

Despite the growing importance of the non-profit sector in providing public services in many developed countries, much remains to be understood in terms of its accounting and accountability mechanisms (Benjamin, 2013; Valentinov, 2011). What has to date been discussed is that non-profit organisations (NPOs) have to respond to multiple stakeholders (Costa \& Pesci, 2016) and therefore have to broaden their accountability mechanism in order to include mission achievement (Ryan et al., 2014; Valentinov, 2011). In discussing broader accountability requirements for the non-profit sector, many scholars have de-emphasised the role of financial reporting information in favour of more non-financial information with a strong focus on mission and mission achievement (Ryan et al., 2014). Within this stream of research many terms have been developed and discussed in order to encompass a more inclusive way of delivering NPOs accountability mechanism, such as 'public' accountability (Coy et al., 2001), 'identity’ accountability (Unerman \& O'Dwyer, 2006), 'relational' accountability (Ebrahim, 2003) and 'social accountability' (Nicholls, 2010; Unerman \& O’Dwyer, 2006).

Social accountability is an important practice within NPOs and relates to the way in which NPOs inform stakeholders about organizations' social, environmental, and ethical achievements (Costa et al., 2014; Ball \& Osborne, 2011b; Gray et al., 2011). Social accountability primarily aims to provide accountability to all stakeholders who might be affected directly or indirectly by the organization. These accountability practices reveal an organization's overall commitment to transparency, while also demonstrating its contributions to community development (Gray et al., 2011). 
Researchers have investigated social accountability in NPOs as a complex, multidirectional, and multi-stakeholder accountability process through which an organization measures and reports on its performance to multiple stakeholders (Najam, 1996; Brown \& Moore, 2001; Ebrahim, 2005; Knutsen \& Brower, 2010: Costa \& Pesci, 2016). By investigating to whom NPOs should be/are accountable, many scholars have analysed which stakeholders are affected by NPO activities namely donors, funders, beneficiaries, workers, volunteers, and the members themselves (Najam, 1996; Ebrahim, 2003b; Ospina et al., 2002). They have also identified possible outcomes (Benjamin, 2013) or impact measures (Costa \& Pesci, 2016) towards different stakeholders. These studies have mainly concentrated on the sender perspective, seeking to understand how managers broadly implement standards of accountability while determining the amount of attention they pay to different stakeholders in the accountability process (Ospina et al., 2002; Knutsen \& Brower, 2010; Saxton \& Guo, 2011). These researchers have also recognized the importance of the stakeholder's voice in strengthening accountability processes by suggesting how managers should engage with critical stakeholders within their accountability space and how NPOs should consider beneficiaries' perceptions regarding the services delivered (Ospina et al., 2002; Benjamin, 2013; Valentinov, 2011).

To a lesser extent, studies have investigated the receiver perspective, which involves stakeholders' reactions to the NPO's accountability and social accounting process (Ebrahim, 2002; Benjamin, 2008). The receiver's perspective has been investigated primarily by considering the funder's needs (Brown \& Cauglin, 2009); to date, funders have indeed been recognized as the most powerful stakeholders in NPOs, and they are usually the ones who provide a formal request for accountability requirements (Benjamin, 2008; Ebrahim, 2002, 2005). However, there is a complete lack of studies dealing with broader stakeholder perceptions of NPO accountability.

In the for-profit context, several studies have examined information requested by the primary—economically powerful—stakeholders (Epstein \& Freedman, 1994; Azzone et al., 1997; 
Solomon \& Solomon, 2006; de Villiers \& van Staden, 2010). Within this setting, studies have also considered, to a lesser extent, the secondary—less economically powerful—stakeholders (O'Dwyer et al., 2005a, 2005b; Tilt, 1994). However, in the NPO context, these kinds of studies are fragmented and underexplored (O’Dwyer, 2002).

To fill this gap, this paper seeks to analyse the receiver perspective on NPO accountability, with specific reference to the primary stakeholders' perceptions of social reporting in an Italian cooperative bank; this paper considers the members' viewpoints in great detail. This research adopts a cross-disciplinary perspective because it deals both with the concept of NPO accountability—with reference to the receiver perspective - and with a social accounting project in a non-profit context. By developing this nexus of issues in different disciplines (NPO accountability and social reporting), this paper makes a contribution to the advancement of knowledge in both of them. First, it considers the receiver perspective of social reporting, thus contributing to the literature on NPO accountability by investigating whether social reporting is (or is not) accepted by the primary stakeholder in a cooperative bank context (Jäger and Beyes, 2010; Benjamin, 2008; Ebrahim, 2003b, 2005; Ospina et al., 2002). Second, it offers an understanding of whether the NPO context could extend our knowledge on the receiver perspective of social and environmental reporting (O’Dwyer et al., 2005a, 2005b).

To achieve the objective of this research, we administered 262 questionnaires, based on Bryman's (1988) survey, to one cooperative bank with a strong presence in northern Italy. In order to better understand why primary stakeholders are fully satisfied with the CB's social reporting, we complemented the surveys with an analysis of the CB's social reports from 1999 to 2011.

The remainder of the paper is organized as follows: the next section introduces the concept of NPO accountability by emphasizing its relational dimension towards different stakeholders in order to highlight the gap in the literature. Section two reviews prior studies that examine primary stakeholders' views of social reporting in different countries. The next section describes the 
research context by introducing the cooperative bank setting and its multiple-stakeholder nature. Section four presents the methodology by describing the survey used in this research. This description includes the questionnaire, pre-test, and pilot test as well as the content analysis used to complement the survey results. The final section discusses the results of our analysis before presenting concluding remarks.

\section{Background: Accountability and Social Reporting in the Non-Profit Sector}

To date, NPO accountability has been recognized as an important issue requiring academic investigation (Ryan et al., 2014; Ball \& Osborne, 2011b; Saxton \& Guo, 2011; Valentinov, 2011; Benjamin, 2008, 2013; Ebrahim, 2005). Many scholars have indeed provided significant conceptual frameworks to investigate NPOs' complex accountability systems (Benjamin, 2008; Knutsen \& Brown, 2010; Ebrahim, 2003b; Murtaza, 2012), thereby assisting NPOs in addressing their multiple-accountability mechanisms while describing stakeholders' expectations and needs (Najam, 1996; Brown \& Moore, 2001; Ebrahim, 2005).

By focusing on the sender perspective, many scholars have analysed "to whom" and "for what" NPOs have to be accountable. The "accountability to whom" question deals primarily with stakeholders affected by NPO activities, namely donors, funders, beneficiaries, workers, volunteers, and the members themselves (Edwards \& Hulme, 1996; Najam, 1996; Brown \& Moore, 2001; Ebrahim, 2003a, 2003b; Ospina et al., 2002, Murtaza, 2012). The development of the 'to whom' question reveals that NPOs currently have strongest accountability towards boards and donors, and weakest accountability towards communities and beneficiaries (Murtaza, 2012; Costa et al., 2011; Epstein \& McFarlan, 2011). On the other hand, by addressing the "accountability for what" agenda, scholars have reported on different dimensions, issues, categories, and drivers by identifying and describing the core area(s) to which the NPO should be accountable (Ryan et al., 2014; Andreaus \& Costa, 2014; Mook, 2013; Valentinov, 2011; Quarter \& Mook, 2009; Moore, 2000). 
While dealing with these questions of accountability in NPOs, many scholars have highlighted that an accountability system solely focused on the economic and financial dimension is likely to encounter "accountability myopia" (Ebrahim, 2005). An accountability mechanism that exclusively stresses the economic bottom line will likely be myopic for two reasons: 1) it privileges the relationship with one stakeholder — namely the funders-by overlooking the possibility of being broadly accountable to a variety of stakeholders and the NPO's community (Ryan et al., 2014); and 2) it focuses on short-term efficiency by ignoring the long run. In order to overcome accountability myopia, some authors have pointed out the relevance of enlarging NPO accountability systems by adopting the so-called "social accounting project" (Gray et al., 2011; Ebrahim, 2005; Nicholls, 2010; Unerman \& O'Dwyer, 2006). This project is an innovative practice aimed at extending the scope of traditional financial accounting (i.e., the profit and loss account) in order to embrace wider accountabilities and responsibilities to societal and community groups. Social accounting can foster organizational transparency and therefore enable a potential change in the relationship between NPOs and their stakeholders (Ball \& Osborne, 2011a; Unerman \& O’Dwyer, 2006); it is able to do so by making stakeholders and the public aware of the NPO's activities (Ebrahim, 2003b).

Within the social accounting project for NPOs, many scholars have contributed to the academic debate by addressing conceptual frameworks and reporting on models with the aim of helping NPOs to enhance accountability and social accounting (Andreus \& Costa, 2014; Mook, 2013; McGrath, 2011). These models have contributed to reflecting on the strategic worthiness of NPO accountability by highlighting the urgent need to strengthen accountability towards communities in order to better achieve the two most important purposes of accountability: fostering NPO performance and ensuring greater justice in the global economy (Murtaza, 2012).

In order to reinforce the accountability mechanism in NPOs, many scholars pointed out the need to consider stakeholder responses and activate forms of stakeholder engagement and involvement (McGrath, 2011; Benjamin, 2013, Rixon, 2010; Ospina et al., 2002). Stakeholder 
engagement in NPO accountability may encourage downward accountability to beneficiaries because it helps NPOs to raise questions about their effectiveness and outcome performance (Benjamin, 2008).

The starting point of any stakeholder consultation is to acknowledge the existence of many stakeholders' viewpoints and to adopt various consultative forums with these stakeholders in order to evaluate whether these consultations are effective in increasing NPO accountability (Rixon, 2010). The stakeholder viewpoint concerning NPO accountability and social reporting remains quite unexplored (O’Dwyer et al., 2005a, 2005b). Indeed, much must be further understood in order to increase stakeholder responses to NPO accountability mechanisms and social accounting practices (Gray et al., 2011). This paper contributes to these two related disciplines-NPO accountability and social accounting-by investigating members' perceptions (as primary stakeholders) of social reporting in a cooperative bank context.

\section{Primary Stakeholders' Viewpoint of Social Reporting}

By developing the receiver perspective of NPO accountability, this paper contributes to the literature regarding the stakeholder viewpoint of social reporting. In recent years, there has been an increase in the number of studies investigating stakeholders' viewpoints of companies' social reporting in for-profit contexts (see Table 1) (Epstein \& Freedman, 1994; Tilt, 1994; Deegan \& Rankin, 1997; O’Dwyer, 2002; Al-Khater \& Naser, 2003; O’Dwyer, 2005b; Solomon \& Solomon, 2006; De Villier \& van Staden, 2010). This section presents a review of this literature by focusing on the primary stakeholder and by shedding light on possible motivations leading stakeholders to be interested (or not interested) in social disclosure.

[insert Table 1 here] 
Clarkson (1995) introduced the distinction between primary and secondary stakeholders, considering the primary stakeholders as those "without whose continuing participation the corporation cannot survive as a going concern" (p. 106). The primary stakeholder group traditionally includes employees, customers, suppliers, and shareholders or investors. On the other hand, secondary stakeholder groups are "those who influence or affect, or are influenced or affected by, the corporation, but they are not engaged in transactions with the corporation and are not essential for its survival" (p.107). The relationship level between primary and secondary stakeholders is not unchangeable over time and might differ between companies (Phillips, 2003). For instance, trade unions, pressure groups, regulators, and volunteers are secondary stakeholders in most institutions; however, depending on their activities, these groups can merit primary stakeholder status.

Referring both to primary and secondary stakeholders, studies have investigated the perception of social and environmental reporting (Epstein \& Freedman, 1994; Azzone et al., 1997; Solomon \& Solomon, 2006; de Villiers \& van Staden, 2010; O’Dwyer et al., 2005a, 2005b; Tilt, 1994). This review focuses on the primary stakeholder's perception in a for-profit context in order to better explain how our investigation into primary stakeholders in an NPO context could contribute to this field of research.

Primary stakeholders in for-profit contexts include institutional investors and individual shareholders, both of whom have wealth maximization goals. Many studies have investigated if and how social and environmental information is useful for shareholders' decision-making process. Solomon and Solomon (2006) pointed out that institutional investors consider public disclosures inadequate for their decision-making process; therefore, they usually develop tailored private social and environmental disclosure information. In an attempt to decrease the lack of studies regarding individual investors, Epstein and Freedman (1994) conducted a survey to determine whether investors demand social information from corporations. They also sought to determine the sort of 
information that interests such investors. The authors found that the majority of respondents require product quality information to be included in the annual report; secondarily, individual investors would like to know about environmental activities. The authors also found a strong demand for corporate ethics (72\%), community involvement (72\%), and employee relations (67\%). The research also highlighted the fact that individual investors are willing to be favourable to an auditing process for the social and environmental report, because it can reduce perceptions that social reports are propaganda tools. The authors' results support previous studies documenting a stock market reaction to social disclosures.

Because the research pertaining to social and environmental report users' demands tends to be limited to investigations of investors or investment analysts, it has largely ignored other company stakeholders. Deegan and Rankin (1997) surveyed different stakeholders-i.e., shareholders, brokers, analysts, academics, financial institutions, and review organizations-and highlighted the importance of social and environmental information for decision-making purposes in Australia. In an attempt to discover different motivations based on users' perceptions of social and environmental reporting (not just driven by decision-making purposes), de Villiers and van Staden (2010) surveyed retail investors in different Anglophone countries (Australia, the UK, and the US). They highlighted three main reasons for environmental information requests: investment decision-making, accountability, and investors' own interests. Accountability has been indicated as a reason for such demand, and it implies both responsible environmental management and giving an account of the environmental management actions taken. De Villiers and van Standen's (2010) study not only implies that shareholders require environmental disclosure for more varied reasons than investment decision-making, but it also shows that companies have to disclose several items of information to meet these different requirements.

These studies make evident the paucity of research investigating how various classes of stakeholders assess the importance (or meaninglessness) of social reporting. The lack of research is 
more gaping when we focus on NPO accountability. Therefore, with the aim of filling this gap in the literature, our study investigates members' viewpoints of social reporting at a cooperative bank in Northern Italy. The cooperative bank setting helps us to explore a different meaning of stakeholder viewpoints regarding social reporting. Due to their stakeholder orientation and valuesbased approach, cooperative banks are expected to fulfil their corporate social responsibility (CSR), including accountability $(\mathrm{EACB}, 2013)$. Therefore, it is expected that the members' perspectives of social reporting will reflect this atmosphere of accountability.

\section{Cooperative Banks and their Multiple-Stakeholder Relationships}

The cooperative banking movement was born during a period of economic difficulty in the late $19^{\text {th }}$ century in Europe in order to promote the financial support to local and rural areas (Mook et al., 2015). Today, cooperative banks (CBs, hereafter) continue to be highly represented in sizable urban communities (Mook et al., 2015), playing a strong role in EU economies and banking sectors. In 2010, for instance, CBs involved over 4,000 member banks, 65,000 branches, 750,000 employees, 50 million members, and 176 million customers. Meanwhile, they had deposits valued at 2,852 billion euros, loans worth 3,102 billion euros, and assets valued at 5,524 billion euros-figures accounting for about $20 \%$ of the sector's market share (EACB, 2013). In Italy, CBs have approximately 110,000 employees, 14 million customers, and 2 million members. Holding onethird of the market share for Italian banking deposits, they play a fundamental role in the Italian banking system (EACB, 2013; Bank of Italy, 2014). To understand the major role of CBs, it is also important to note that the Italian co-operative credit sector is the third largest in Europe (11\% of the European co-operative banking sector), after France and Germany (Manetti \& Bagnoli, 2013).

This paper's empirical evidence is based on a survey of primary stakeholders, i.e. the members of an Italian cooperative bank (CB) where the mission imperative (Ryan et al., 2014) is to provide financial services to rural populations and to urban artisans and masters. In essence, CBs 
aim to facilitate banking relationships with SMEs, craftsmen, and farmers, while reducing (or if possible, avoiding) the potential credit access restrictions applied by commercial banks (Jäger \& Beyes, 2010). CBs explicitly seek to work with local communities to enhance their economic and social wellbeing through activities, services, and collaborations with local associations. CB activities are devoted to members - who are concurrently customers - and to local communities, thus fulfilling their sense of responsibility and solidarity (International Co-operative Alliance, 1995). Based on member ownership, CBs differ in nature from commercial and investment banks because their governance structure includes multiple stakeholders. Both employees and customers can be $\mathrm{CB}$ members, including people from the local community, a fact that reflects CBs' social mission to participate in the economic development of the local region. Ultimately, CBs reflect an approach that is not linked solely to the maximisation of shareholder value; on the contrary, CBs aim to maximise value for a larger and more diverse group of stakeholders, promoting the development of the local economy in a socially responsible way (Coco \& Ferri, 2010).

CBs thus show a tension between social and economic objectives and face a dual challenge: as financial institutions, they have to consider their economic and financial performance in terms of profitability, solvency, and efficiency (Relano \& Paulet, 2012); as non-profit institutions, they have to pursue the wellbeing of their stakeholders and the development of the local economy in which they operate (Ayadi et al., 2010).

These challenges impact accountability mechanisms, again reflecting the multi-stakeholder nature. As Dixon et al. (2006) observed, microfinance institutions adhere to three main forms of accountability: i) formal accountability, which is more economic and financially oriented towards the funders and donors; ii) informal accountability, which closely aligns to the needs of the community and society; and iii) combinations of varying degrees of accountability, both formal and informal. 
Microfinance institutions face several challenges due to the co-existence of these different forms of accountability; by design, they follow more relational and informal accountability methods (Dixon et al., 2006).In practice, this situation inherently increases the complexity involvedaccountability means simultaneously combining and satisfying vertical and horizontal demands, which are guided by different criteria. The criteria for horizontal accountability "are implicit, and subject to change with shifts in societal values, beliefs, and public sentiments" (Dixon et al., 2006, p. 419). In horizontal accountability, members of microfinance institutions expect relational reciprocity and therefore require a more informal and unspoken form of accountability, a feature that reflects the original intention of microfinance: to favour so-called "socialised accountability" (Roberts, 1996) because of its solidaristic nature.

This paper investigates the members' perspective of this "socialised accountability" (Roberts, 1996) in the form of social and environmental reporting via a survey of 262 members of an Italian cooperative bank. We complement this investigation with a content analysis of the CB's social and environmental report in order to better understand the characteristics/themes inherent in this socialised form of accountability.

\section{Research Design and Method}

The research in this paper has been conducted with members of a CB located in Italy's Trentino region (north-eastern Italy). We chose this $\mathrm{CB}$ for two main reasons: first, CBs represent almost $92 \%$ of the banking institutions in Trentino, and the CB under investigation is the second largest in the region (Giagnocavo et al., 2012); second, the selected CB has a long tradition of drawing up social and environmental reports, with its first stand-alone social and environmental report dating 
back to $1999 .{ }^{1}$ As the content analysis reveals later in this paper, the CB used these reports to nurture a sense of "socialised accountability" and transparent dialogue mainly with its members and the local community.

\section{Survey Design}

For the purposes of this study, we adopted a survey (Bryman, 1988) based on 262 questionnaires. The questionnaire was designed with 36 closed questions and one open-ended question. Questions using the closed form included two kinds of answers: multiple-choice answers and a five-point Likert scale. When respondents need to choose one option on a scale between 1 (strongly disagree) and 5 (strongly agree), the Likert scale is frequently adopted (Epstein \& Freedman, 1994; Deegan \& Rankin, 1997; Al-Khater \& Naser, 2003; O’Dwyer et al., 2005b; de Villiers \& van Staden, 2010). A cover letter was included specifying the most important aspects of the questionnaire, and members were informed that the data would be kept anonymous for the protection of personal data in accordance with Italian law (D.Lgs. n. 196/2003). It also explained the focus of this study and introduced those responsible for this research and its data. Data collection started in May 2012 after an initial phase elaborating on the survey, pre-test, and pilot-test as well as meeting with the CBs involved in this study. In order to facilitate communication with members, two forms of survey questionnaires were used: printed and online formats. Printed questionnaires were submitted to the members during the CB's Annual Assembly ${ }^{2}$ and were collected in May 2012. In September, 2012, online questionnaires were sent to all the members who had an email account but were not present during the Annual Assembly.

\footnotetext{
1 Please also note that the Italian Banking Association delivered the industry-specific standards for social and environmental reports in 2001. Therefore, the cooperative bank under investigation could be considered a pioneer in delivering these practices, given that its first stand-alone social and environmental report dates back to 1999.

${ }^{2}$ Please note that members receive a hard copy of the CB's social report every year before the AGM.
} 
In order to ensure clarity and comprehensiveness, we piloted the questionnaire with three researchers from the University of Trento and three members of a cooperative bank in order to gather feedback regarding questions or difficulties in comprehension. Afterwards, we conducted a pilot test in April 2012 with postgraduate students from the University of Trento (Italy) in order to evaluate specific questions concerning the questionnaire format (Zoltan, 2010). Thereafter, the questionnaire was accepted by a group of employees at the cooperative bank being researched. Following these steps, we felt that the survey was ready to be administered.

\section{Content Analysis of the Social and Environmental Reports}

Though this paper focuses on the receiver perspective of the social and environmental report, we performed a content analysis in order to better interpret our results from the members' viewpoint. Therefore, the data collected from the reports will not be a focal point of this paper; on the contrary, they will complement the member survey and contribute additional insights to the analysis.

We conducted a content analysis (Abbott \& Monsen, 1979) on the CB's social and environmental reports from 1999 to $2011^{3}$ (13 years), thus considering all of the social and environmental information reported. Some scholars consider sentences to be the most appropriate unit of analysis (Unerman, 2000). Compared to characters or words, sentence-level analysis diminishes the number of reliability issues and difficulties caused by discerning the meaning of smaller units. Based on these arguments, this paper adopts the number of sentences as the unit of analysis. To categorise information, we began our analysis with the national industry-specific standards for the banking sector, developed by the Italian Banking Association in 2001 and 2006 (Associazione Bancaria Italiana (ABI), 2001; 2006). The researchers adopted emergent coding whenever the reports included social and environmental issues beyond those suggested in the Italian

\footnotetext{
${ }^{3}$ Because the survey was distributed to the AGM in May 2012, the last social report that members would have seen was from 2011.
} 
Banking Association guidelines (Haney et al., 1998). The cooperative nature of the analysed banks makes it essential to disclose information not only to the shareholders, but also to the members. As a result, during the coding process, the researchers considered each piece of social and environmental information disclosed in terms of five stakeholders: community, customers, employees, suppliers, and members.

To ensure the reliability of the data collection and coding process (Unerman, 2000), two researchers analysed the 13 reports over three rounds, independently — thus ensuring stability and reproducibility. Discrepancies were re-analysed and differences resolved, and a priori rules were established for accurate data collection procedures, facilitating the distribution of information into coding units before re-distributing the coding units into categories. The content analysis was conducted manually in order to facilitate more familiarity with the social and environmental reports.

\section{Results and Discussion}

Response Rates and Tests for Bias

Questionnaires were delivered to all 1,006 members present during the annual meeting. Respondents could deliver their completed questionnaires to researchers or to the cooperative bank branches. If they took the survey online, they could deliver their responses through the Lime Survey software. 215 answered questionnaires were received during the annual meeting, and 47 more were collected by the bank branches between the meeting and September, 2012. No questionnaires were answered online. A total of 262 questionnaires were returned, resulting in a response rate of $26.04 \%$. During the evaluation of the dataset, some incomplete questionnaires were excluded from the sample, leaving a total of 232 usable questionnaires (23.06\% of the total distributed). According to Fowler (2002), a response rate of less than 20 percent is unlikely to provide credible statistics about the population. This study has a usable response rate of a $23.06 \%$, which can be considered sufficient for our analysis. 
To test for response bias, we compared the responses received during the annual meeting (215) with those received afterwards (47) (Oppenheim, 1966). A t-test of the average differences between early and later respondents revealed no significant differences between the two groups.

\section{The Respondents}

The majority of the respondents were male. They were mainly mature people, with an average age of 53.4 years $(57.3 \%$ were over 50 years of age and only $6.7 \%$ were 30 years old or younger) and a low education index (i.e., just $20.8 \%$ of valid questionnaires indicated a degree or post-graduate education).

For a deeper understanding of the relationship between members and the $\mathrm{CB}$, specific questions were included, leading to the observation that respondents were loyal to the cooperative banking system, particularly to the $\mathrm{CB}$ under investigation. In fact, $73 \%$ of the surveyed subjects exclusively have relationships with cooperative banks, thus indicating the strength of the cooperative culture in the Trentino region.

Through multiple choice questions, the research tried to identify members' acquaintance with social reporting. Our analysis shows that the majority of respondents (92\%) were aware of the existence of a social report (as a document in itself) and that they understood its function, while $8 \%$ claimed to have no knowledge of this document. This positive result highlights that members of the cooperative bank are directly or indirectly engaged in the bank's activities and projects, including the social and environmental disclosure project.

\section{Members'Perceptions of Social Reporting}

Using five-point Likert scale questions, respondents demonstrated a substantial demand for a greater level of mandatory requirements. Indeed, $74 \%$ of the respondents highlighted the need for compulsory adoption of the social and environmental report in Trentino's cooperative bank system 
(Table 2). $81.5 \%$ of the respondents also recognized the importance of internationally-accepted standards in drawing up the social and environmental report, thus avoiding haphazard solutions (Table 2). However, the call for greater standardization in social reporting does not automatically imply a compulsory nature; indeed, most of the internationally-accepted standards (e.g., the Global Reporting Initiative, GRI) remain voluntary. Nevertheless, our survey shows that when respondents favour more standard-setting requirements in delivering social reports $(81.5 \%)$, they also tend to support compulsoriness $(83.6 \%)$.

In terms of the medium to be adopted when disseminating social and environmental information, our findings support the idea that members privilege the stand-alone social and environmental report as the most effective solution (3.78, Table 2). Members consider the annual report the "second-best" solution (3.61), and other mediums less significant, including the company website or brochures as well as newspapers and magazines (2.68).

Our results contrast slightly with previous studies claiming that primary stakeholders consider the annual report to be the most significant source of disclosure for social and environmental information (Al-Khater \& Naser, 2003; Deegan \& Rankin, 1997; Epstein \& Freedman, 1994). These differences should be interpreted in light of the cooperative banking setting analysed in this paper. Indeed, as Dixon et al. (206) have highlighted, these kinds of organization prefer a more relational, socialised, and less-formal kind of accountability. The stand-alone social and environmental report usually uses less technical language because it is addressed to a variety of stakeholders, indicating that the members favour a more "horizontal" kind of accountability (Dixon et al., 2006), which is by definition, more oriented to strengthening mutual ties.

This idea also is confirmed by the third question reported in Table 2: CB members support the statement that the best way to deliver social reporting is through narrative and descriptive data, information that can be read and understood easily by stakeholders $(80.9 \%$ of respondents agreed or strongly agreed). This information confirms the assertion that horizontal accountability, including 
less formal and technical accountability, is preferred because of the desire to include narratives and descriptive information in the stand-alone social and environmental report. In contrast, research in the profit-oriented context (Al-Khater and Naser, 2003) strongly supports a combination of information - descriptive, quantitative, and monetary - for social reporting disclosures.

\section{[Insert here Table 2]}

\section{Rationales Driving Demand for Social Reporting}

With reference to for-profit companies, previous studies have highlighted that institutional and individual investors are primarily motivated by decision-making purposes when it comes to social and environmental reporting (Solomon \& Solomon, 2006; Epstein \& Freedman, 1994; Deegan \& Rankin, 1997). In an attempt to extend this field of exploration, de Villiers and van Staden (2010) pointed out three main reasons for environmental information requests: investment decisionmaking, accountability, and protecting one's own interests. Our study supports accountability as the principal motivation behind the respondents' demands. Through a five-point Likert scale, respondents strongly affirmed the desire to receive information on activities undertaken on behalf of members and the local community (86.4\%), such as the awareness that the $\mathrm{CB}$ is conducting a socially responsible business $(84.6 \%)$. Their view that "this is the right thing to do" $(82.30 \%$ of the respondents, Table 3) links with arguments made about "moral accountability".

[Insert Table 3 here]

\section{Verification of Social Reporting}

Table 4 shows a strong demand for verification in the CBs' social and environmental information, preferably developed by persons or bodies external to the organization. The analysis clearly shows 
that there is a demand for verification of social reporting by independent bodies external to the bank (72.4\% agree or strongly agree) — even if a solution with an internal working group is accepted to a certain degree (48.20\%). Meanwhile, $76.60 \%$ of respondents strongly reject the idea of social and environmental reports being self-referential documents lacking any kind of verification.

In terms of people or organizations who could be in charge of the verification process, most respondents suggested an independent external auditor with previous expertise on social and environmental issues (70.1\%). Respondents also shared varying perspectives related to the level of expertise necessary for an external auditor: $56.5 \%$ agreed or strongly agreed that the external auditor should be an expert on annual reports, and $45.8 \%$ of respondents favoured recognizing a role for the CB Federation. The presence of internal auditors - either as an internal working group or as an internal expert—was a less preferred option (36.9\% and $24.10 \%$, respectively).

Our findings are consistent with previous studies (Epstein \& Freedman, 1994; O’Dwyer, 2005b), suggesting that external certification decreases members' perceptions of potential data manipulation. Such controversies have occurred in major ethical violation scandals that went public, causing catastrophic consequences for stakeholders. Therefore, even in the CB context where the mission is socially-oriented with a foundation of ethics and values, members highlight a desire for neutral and credible reports. This result could be considered a reflection of recent ethical scandals that have damaged the entire global banking system (Giagnocavo et al., 2012).

\section{[Insert Table 4 here]}

\section{Current Satisfaction with Social Reporting}

The last section of our questionnaire moves to the analysis of members' perceptions in relation to social reporting drawn up by the cooperative bank under investigation. The majority (86\%) of respondents are confident that the $\mathrm{CB}$ under investigation drafts its social reporting on its own, 
without seeking support from an external consultant. A small percentage (4\%) is unaware of this reporting. $35 \%$ of the respondents correctly identified that this $\mathrm{CB}$ has drawn up its own social reporting for more than 10 years.

Intending to identify members' reading trends, some questions focused on the regularity with which members read the available documents, showing that $41 \%$ of respondents read each new social reporting release, while $36 \%$ are occasional readers. More specifically, $39 \%$ of respondents carefully read only the section(s) they consider most interesting, and $20 \%$ read each section carefully. In order to explore members' satisfaction, respondents were asked to evaluate the social reports of the cooperative bank under investigation. Evidence in Table 5 shows that $87 \%$ of respondents are satisfied (73\%), or completely satisfied (14\%) with the CB's social report.

[Insert here Table 5]

Table 6 highlights the fact that respondents clearly consider social and environmental disclosure useful (93.1\%), credible (84.9\%), transparent (78.7\%), and complete (72.9\%). Furthermore, members perceive the CB's social reports disclosure as being of high quality and credible.

[Insert here Table 6]

\section{Cooperative Banks’ Motives for Delivering Social Reporting}

Table 7 shows the members' views of the cooperative bank's purpose to disclose its social information. Our analysis reveals three main purposes in the eyes of members: $88.5 \%$ of the respondents consider social reporting as a tool to communicate the CB's activities to members; 82.1\% highlight adoption of social reporting practices as enhancing trust among members; and 
$78.4 \%$ believe that social reporting is a form of disclosure encouraging transparency with the community. Confirming the positive conviction about this $\mathrm{CB}$, less than $20 \%$ of respondents believe that the CB uses its reporting for other intentions, such as decreasing external pressure (14.6\%), gaining an economic return (17.5\%), or imitating other businesses $(18.8 \%)$. Therefore, while members recognize social reporting as important to themselves for communicating and building trust, they also acknowledge that social reporting is an important tool for communicating and being transparent in the community.

\section{[Insert here Table 7]}

Our findings show that members have a positive perception of the activities undertaken by this cooperative bank, which could be a reflection of the strong connection built between the cooperative bank and this local territory/community (Ayadi et al., 2010). Moreover, these results can be linked to the horizontal accountability framework, which is based on the idea of Roberts' "socialised" accountability (1996). Socialised accountability broadly refers to the relational dimension of accountability—supposedly complex, multi-directional, and multi-stakeholder—due to the different cognitive needs of meeting stakeholders' various expectations (Ebrahim, 2003). Relational accountability "does not stand alone, but is reflective of relationships among organisational actors embedded in a social and institutional environment” (Dixon et al., 2006, p. 407). Relational accountability thus reflects a "reciprocal dependence" (Dixon et al., 2006) between the NPO and its stakeholders, in that both the organisation and its stakeholders are involved and implicated.

Content of the Reports (1999-2011) 
The content analysis of these social and environmental reports (from 1999 to 2011) helped us to better interpret the rationales behind the high level of satisfaction revealed by the questionnaires. In terms of the quantity of disclosures, Table 8 clearly illustrates that these reports primarily have addressed members and the community. The majority of the information relates to the cooperative banks' ethical values and their initiatives supporting the local community. The manual content analysis, however, helped us to better understand the performance of this form of accountability. Indeed, by referring to the Dixon et al. (2006) framework considering vertical (formal) and horizontal (informal) types of accountability within micro-finance institutions, we observed that the social accountability provided in the social reports was prominently horizontal. This finding has been highlighted in two main ways: i) the information provided mainly relates to the CB's values and beliefs — such as cooperation, reciprocity, and territorial embeddedness (Giagnocavo et al., 2012); and ii) the information is not only textual, like that reported in the analysis, but also contains non-textual information, such as pictures, photos, and images. Managers use such information to impress the reader and foster a process of identification with the organisation (Mancia, 2006).

Both of these dimensions are related to a form of horizontal accountability, which is by definition, less technical and based more on the relational dimension; therefore, our study also supports a relational approach of NPOs accountability. The members of the CB under investigation strongly affirm that social reporting is undertaken in order to communicate with members, to build trust by improving relations with the community, and to increase transparency. Indeed, as the content analysis confirmed, the information provided in the reports mainly sought to describe the promotion of sustainable community development (Giagnocavo et al., 2012). The social and environmental information provided confirms that the role of cooperative banks extends beyond the mere provision of credit. The reports from 1999 to 2011 confirm that the CB was proactive in encouraging business and social development, often filling a civil society vacuum. They used the relational dimension to spread information, knowledge, and values (such as trust and cooperation) 
in order to strategically promote local community development, thus fostering relationships between different stakeholders (Giagnocavo et al., 2012).

[Insert here Table 8]

\section{Discussion and Conclusions}

In this study, we investigated the receiver perspective of NPO accountability by focusing on the primary stakeholders' perceptions (i.e. the members) of social reporting in a northern Italian cooperative bank. The paper highlights the ability of the accountability system and social reporting to meet members' information needs, thus demonstrating a high level of member satisfaction in terms of the information provided.

With the intent of contributing to the fragmented studies in this area (Ebrahim, 2002; Benjamin, 2008; O’Dwyer, 2005b), we analysed 232 questionnaires received during our survey and complemented this research with a content analysis of social and environmental reports spanning 13 years. The results highlight that members consider $\mathrm{CB}$ accountability to be effective when dealing with specific documents, i.e. stand-alone social and environmental reporting $(68.5 \%$ of the respondents). Respondents also feel that the social report should be mandated and verified by external independent bodies. Participants identified social reporting as providing a high level of satisfaction (87\%): a large portion of the sample considered social reporting to be useful, credible, transparent, and complete.

Our study supports the idea that a broader NPO accountability mechanism is needed because the traditional measures of accountability do not provide sufficient information on how NPOs perform (Valentinov, 2011). Indeed, our survey reveals that the stand-alone social reporting developed from 1999 by the CB under investigation is viewed by the primary stakeholder as an effective means of communicating about the performance compared to the annual report. Indeed, by 
analysing the content of the report in a broad period of time (1999-2011) we observed that two main issues: (i) the volume of the disclosure (measured by number of sentences) is mainly addressed to the members and the community; (ii) along with the textual information analyzed, the reports also contain visual/non-textual information with the aim of represents value and beliefs.

Therefore, from the "reports side" we measured a prominent adoption of the social and environmental report as a mean to communicate with the members with regard to the sense of community, the values of cooperation and solidarity. From the "reader side" we monitored an acknowledgment of the members in terms of satisfaction regarding the information received. These information are valued and considered useful by the members in order to build their sense of belong to that specific cooperative community.

Along with this perspective, our analyses reveal that the CB's social reporting is seen-by its members - as a reliable accountability system that focuses on activities related to mission statements, thus reinforcing the importance of focusing NPO accountability on mission achievement (Ryan et al., 2014). In other words, social reporting is used to provide evidence of the CB's creation of value within the community, strengthening stakeholder confidence, and identifying the suitability of impact on the local community (Costa \& Pesci, 2016; Mook, 2013).

By developing a cross-disciplinary perspective, this paper deals both with NPO accountability and the social accounting research literature, thus contributing to them in several ways. First, it enhances our knowledge of accountability for NPOs by supporting the relevance of the stakeholder viewpoints (McGrath, 2011; Benjamin, 2008, 2013; Rixon, 2010; Ospina et al., 2002, Ebrahim, 2003b, 2005) and by showing the potential of social reporting in strengthening NPOs accountability to different stakeholders (Valentinov, 2011; Ryan, 2014).

Second, the paper offers a new understanding regarding motivation for delivering social reporting by extending previous knowledge in the for-profit context (Solomon \& Solomon, 2006; 
Epstein \& Freedman, 1994; Deegan \& Rankin, 1997; de Villiers \& van Staden, 2010; O’Dwyer et al., 2005a, 2005b). In this context, the receiver of social reports have been seen as driven mainly by decision-making purposes; this paper shows that members (primary stakeholders) in the NPO context accept social reporting as a way to foster "moral accountability." Our findings show that members have a positive perception of activities reported by the $\mathrm{CB}$ in their social and environmental reports because of the members found this narrative more effective in dealing with social issues. Social reporting is thus seen as a strategic response to address social impact issues in the CB's local community.

Finally, the paper highlights that the social and environmental information delivered to the members is actually valued and used by these stakeholders. Therefore, beyond the traditional link between corporate social reporting and corporate financial reporting (or market value), this paper supports the idea that in a nonprofit context members (and potentially other stakeholders) can posit a value to the social and environmental information provided by the organization. This information has indeed a value because it fosters trust, transparency and NPO' values.

The paper presents some limitations. In cooperative banks, membership only includes members, members-customers, and members-employees; therefore, the results may present some bias because it is not possible for participants to "separate" themselves from their positions as members and employees. Further studies could try to better analyse the different forms of membership and social reporting perceptions. Moreover, future research could investigate the viewpoint of other stakeholders (i.e., beneficiaries, managers, volunteers) in order to broaden our knowledge on the receiver perspective of NPO accountability. Additional studies could also explore different methodologies, such as interviews, in order to better understand various nuances of the moral accountability declared by the members in this research. 


\section{References}

Abbott, W.F. and Monsen, R.J. (1979), On the measurement of corporate social responsibility: Selfreported disclosures as a method of measuring corporate social involvement, Academy of Management Journal, 22(3), 501-515.

Al-Khater, K., and K. Naser (2003), Users' perceptions of corporate social responsibility and accountability: Evidence from an emerging economy, Managerial Auditing Journal, 18(6/7), 538-548, doi:10.1108/02686900310482678.

Andreaus, M., and E. Costa (2014), Toward an Integrated Accountability Model for Non-Profit Organizations, in Costa E., Parker L. and M. Andreaus, (Eds.), Accountability and Social Accounting for Social and Non-profit Organizations, Advances in Public interest Accounting, Emerald Group Publishing, Bradford, United Kingdom, 153-176.

Ayadi, R., Llewellyn, D. T., Schmidt, R. H., Arbak, E., and W. P. De Groen (2010), Investigating diversity in the banking sector in Europe. Key development, performance and role of cooperative banks, Centre for European Policy Studies, Brussels.

Azzone, G., Brophy, M., Noci, G., Welford, R., and W. Young (1997), A stakeholders' view of environmental reporting, Long Range Planning, 30 (5), 699-709.

Ball, A. and S.P. Osborne (2011a), Introduction: Accounting for the common good? in A. Ball and S. P. Osborne (Eds.), Social accounting and public management. Accountability for the common good, Routledge, New York, NY, 1-7.

Ball, A., and S. P. Osborne (Eds.) (2011b). Social accounting and public management. Accountability for the common good, Routledge, New York, NY.

Bank of Italy (2014), Relazione annuale, Banca d'Italia, Roma, IT.

Benjamin L. M. (2008), Account space: How accountability requirements shape non-profit practice, Nonprofit and Voluntary Sector Quarterly, 37(2), 201-223, doi: $10.1177 / 0899764007301288$ 
(2013), The potential of outcome measurement for strengthening nonprofits' accountability to beneficiaries, Nonprofit and Voluntary Sector Quarterly, 42(6), 1224-1244, doi: $10.1177 / 0899764012454684$

Brown, L. D., and M. H. Moore (2001), Accountability, strategy, and international nongovernmental organizations, Nonprofit and Voluntary Sector Quarterly, 30(3), 569-587, doi: $10.1177 / 0899764001303012$

Brown, E and K. Caughlin (2009), Donors, ideologues and bureaucrats: government objectives and the performance of the non-profit sector, Financial Accountability \& Management, 25(1), 99-114, doi:10.1111/j.1468-0408.2008.00467.x

Bryman, A. (1988), Quantity and quality in social research, Routledge, London and New York.

Clarkson, M. B. E. (1995), A stakeholder framework for analyzing and evaluating corporate social performance, Academy of Management Review, 20(1), 92-117.

Coco, G., and G. Ferri (2010), From shareholder to stakeholder finance: A more sustainable lending model, International Journal of Sustainable Economy, 2(3), 352-64.

Costa E., Parker L., and M. Andreaus (Eds.) (2014), Accountability and social accounting for social and non-profit organizations: Advances in public interest accounting, Emerald Group Publishing, Bradford, United Kingdom.

Costa E., and C. Pesci (2016), Social impact measurement: Why do stakeholders matter? Sustainability Accounting, Management, and Policy Journal, 7(1), 99-104, doi: 10.1108/SAMPJ-12-2014-0092

Costa, E., Ramus, T. and M. Andreaus (2011), Accountability as a managerial tool in non-profit organizations: Evidence from Italian CSVs, Voluntas: International Journal of Voluntary and Nonprofit Organizations, 22(3), 470-493, doi: 10.1007/s11266-011-9183-7 
Deegan, C., and M. Rankin (1997), The materiality of environmental information to users of annual reports, Accounting, Auditing and Accountability Journal, 10(4), 562-583, doi: $10.1108 / 09513579710367485$

De Villiers, C. and C. J. van Staden (2010), Shareholders' requirements for corporate environmental disclosures: A cross, The British Accounting Review, 42(4), 227-240, doi:10.1016/j.bar.2010.08.002

EACB European Association of Co-operative Banks (2013), Annual report. More than a bank, a cooperative bank, Brussels, Belgium.

Ebrahim, A. (2002), Information struggles: The role of information in the reproduction of NGO funder relationships, Nonprofit and Voluntary Sector Quarterly, 31(1), 84-114, doi: $10.1177 / 0899764002311004$

- (2003a), Making sense of accountability: Conceptual perspectives for northern and southern nonprofits, Nonprofit Management \& Leadership, 14(2), 191-212, doi: $10.1002 / \mathrm{nml} .29$

(2003b), Accountability in practice: Mechanisms for NGOs, World Development, 31(5), 813-829, doi:10.1016/S0305-750X(03)00014-7

- (2005), Accountability myopia: Losing sight of organizational learning, Nonprofit and Voluntary Sector Quarterly, 34(1), 56-87, doi: 10.1177/0899764004269430

Edwards, M., and D. Hulme (1996), Too close for comfort? The impact of the official aid on nongovernmental organizations, World Development, 24(6), 961-973.

Epstein, M. J. and M. Freedman (1994), Social disclosure and the individual investor, Accounting Auditing and Accountability Journal, 7(4), 94-109, doi: 10.1108/09513579410069867

Epstein, M. J. and F. W. McFarlan (2011), Measuring the efficiency and effectiveness of a nonprofit's performance, Strategic Finance, 93(4), 27-34.

Fowler, F. J. (2002), Survey research methods (3rd ed.), Sage, Thousand Oaks, CA. 
Giagnocavo, C., Gerez, C., and J. Sforzi (2012), Cooperative bank strategies for social-economic problem solving: Supporting social enterprise and local development, Annals of Public and Cooperative Economics, 83(3), 281-315.

Gray, R., Dillard, J., and C. Spence (2011), A brief re-evaluation of "The Social Accounting Project.” In A. Ball \& S.P. Osborne (Eds.), Social accounting and public management. Accountability for the common good, Routledge, New York, NY, 12-22.

Haney, W., Michael, R., Cengiz, G. and Fierros E. (1998). Drawing on education: using student drawings to promote middle school improvement, Schools in the Middle, 7(3), 38-43.

Jäger, U. and Beyes, T. (2010), Strategizing in NPOs: A case study on the practice of organizational change between social mission and economic rationale, Voluntas: International Journal of Voluntary \& Nonprofit Organizations, 21(1), 82-100.

Knutsen W. L., and R.S. Brower (2010), Managing expressive and instrumental accountabilities in nonprofit and voluntary organizations: A qualitative investigation, Nonprofit and Voluntary Sector Quarterly, 39(4), 588-610, doi: 10.1177/0899764009359943

Mancia, M. ed., (2006), Psychoanalysis and Neuroscience. Milano: Springer

Manetti, G. and Bagnoli L., (2013), Mutual and social efficiency of Italian cooperative banks: an empirical analysis, Annals of Public and Cooperative Economics 84(3), 289-308

McGrath, D. (2011), Stakeholder responses to social and environmental reporting model for credit union sector. In A. Ball \& S.P. Osborne (Eds.) Social accounting and public management. Accountability for the common good, Routledge, New York, NY, 203-216.

Mook, L. (Ed.) (2013), Accounting for social value. University of Toronto Press, Toronto, Buffalo, and London.

Mook, L., Maiorano, J., and Quarter, J. (2015), Credit unions: Market niche or market accommodation?, Nonprofit and Voluntary Sector Quarterly, 44(4), 814-831, doi: $10.1177 / 0899764014538121$ 
Moore, M. H. (2000), Managing for value: Organizational strategy in for-profit, nonprofit and governmental organizations, Nonprofit and Voluntary Sector Quarterly, 29(1), 183-208, doi: $10.1177 / 0899764000291$ S009

Murtaza, N. (2012), Putting the lasts first: The case for community-focused and peer-managed NGO accountability mechanisms, Voluntas: International Journal of Voluntary and Nonprofit Organizations, 23,109-125, doi: 10.1007/s11266-011-9181-9

Najam, A. (1996), NGO accountability: A conceptual framework, Development Policy Review, 14, 339-353, doi: 10.1111/j.1467-7679.1996.tb00112.x

Nicholls, A. (2010), Institutionalizing social entrepreneurship in regulatory space: Reporting and disclosure by community interest companies, Accounting, Organizations and Society, 35, 394-415, doi: 10.1016/j.aos.2009.08.001

O'Dwyer, B. (2002), Managerial perceptions of corporate social disclosure: An Irish story, Accounting, Auditing and Accountability Journal, 15(3), 406-436, doi: $10.1108 / 09513570210435898$

O’Dwyer, B., Unerman, J., and Bradley, J. (2005a), Perceptions on the emergence and future development of corporate social disclosure in Ireland: Engaging the voices of nongovernmental organisations, Accounting, Auditing and Accountability Journal, 18(1), 14-43, doi: $10.1108 / 09513570510584647$

O’Dwyer, B., Unerman, J., and Hession, E. (2005b), User needs in sustainability reporting: perspectives of stakeholders in Ireland, European Accounting Review, 14(4), 759-787, doi: $10.1080 / 09638180500104766$

Oppenheim, A. N. (1966), Questionnaire design and attitude measurement. Heinemann, London. Ospina, S., Diaz, W., and O’Sullivan, J. F. (2002), Negotiating accountability: Managerial lessons from identity-based nonprofit organizations, Nonprofit and Voluntary Sector Quarterly, 31(1), 5-31, doi: 10.1177/0899764002311001 
Phillips, R. (2003), Stakeholder legitimacy, Business Ethics Quarterly, 13(1), 25-41.

Piatti, D. (2013), Social and environmental performance and Social Disclosure in Italian local banks, Bancaria, 11, 34-52.

Quarter, J., Mook, L., \& Armstrong, A. (2009), Understanding the social economy: A Canadian perspective, University of Toronto Press, Toronto.

Ryan C., Mack J., Tooley S. and H. Irvine (2014), Do Not-For-Profits Need Their Own Conceptual Framework?, Financial Accountability \& Management, 30(4), 383-402, doi: 10.1111/faam.12044

Relano, F. and Paulet, E. (2012), Corporate responsibility in the banking sector: A proposed typology for the German case, International Journal of Law and Management, 54(5), 379393, doi: $10.1108 / 17542431211264269$

Rixon, D. (2010), Stakeholder engagement in public sector agencies: Ascending the rungs of the accountability ladder, International Journal of Public Administration, 37(7), 347-356, doi: $10.1080 / 01900691003606006$

Saxton, G.D. Guo, C. (2011), Accountability online: Understanding the web-based accountability practices of nonprofit organizations, Nonprofit and Voluntary Sector Quarterly, 40(2), 270295, doi: $10.1177 / 0899764009341086$

Solomon, J. F., and Solomon, A. (2006), Private social, ethical, and environmental disclosure, Accounting, Auditing and Accountability Journal, 19(4), 564-591, doi: $10.1108 / 09513570610679137$

Tilt, C.A. (1994), The influence of external pressure groups on corporate social disclosure: Some empirical evidence, Accounting, Auditing and Accountability Journal, 7(4), 47-72.

Unerman, J. (2000), Methodological issues - Reflections on quantification in corporate social reporting content analysis, Accounting, Auditing \& Accountability Journal, 13(5), 667-681. 
Unerman, J. and O'Dwyer, B. (2006), Theorising accountability for NGO advocacy, Accounting, Auditing \& Accountability Journal, 19(3), 349-376, doi: doi.org/10.1108/09513570610670334

Valentinov, V. (2011), Accountability and the public interest in the nonprofit sector: a conceptual framework, Financial Accountability \& Management, 27(1), 33-42, doi: 10.1111/j.14680408.2010.00514.x

Zoltan, D. (2010), Questionnaires in second language research: Construction, administration and processing, (2 $2^{\text {nd }}$ ed.) Routledge, New York. 


\section{Tables}

Table 1. Summary of Prior Studies Focused on Stakeholder Perceptions of Social and Environmental Reports.

\begin{tabular}{|c|c|c|c|c|c|c|}
\hline $\begin{array}{l}\text { Author } \\
\text { (s) }\end{array}$ & $\begin{array}{l}\text { Country/ } \\
\text { Method* }\end{array}$ & Respondents & Sample & $\begin{array}{l}\text { Answ } \\
\text { ers }\end{array}$ & $\%$ & Results \\
\hline $\begin{array}{l}\text { Epstein } \\
\& \\
\text { Freedm } \\
\text { an } \\
(1994)\end{array}$ & $\begin{array}{l}\text { USA } \\
\text { (Quest) }\end{array}$ & $\begin{array}{l}\text { Individual } \\
\text { investors } \\
\text { (primary stk) }\end{array}$ & 3,000 & 246 & $8.2 \%$ & $\begin{array}{l}\text { There is a demand for social and } \\
\text { environmental information, } \\
\text { especially information relating to } \\
\text { environmental issues, safety, and } \\
\text { product quality. }\end{array}$ \\
\hline $\begin{array}{l}\text { Tilt } \\
\text { (1994) }\end{array}$ & $\begin{array}{l}\text { Australia } \\
\text { (Quest) }\end{array}$ & $\begin{array}{l}\text { Pressure } \\
\text { group } \\
\text { (secondary } \\
\text { stk) }\end{array}$ & 146 & 59 & $46.8 \%$ & $\begin{array}{l}\text { Pressure groups use the social } \\
\text { information; however, they } \\
\text { consider it insufficient and not } \\
\text { very credible. They also favor } \\
\text { standardizations or legislation to } \\
\text { ensure that companies are really } \\
\text { sticking to their responsibilities. }\end{array}$ \\
\hline $\begin{array}{l}\text { Deegan } \\
\& \\
\text { Rankin } \\
(1997)\end{array}$ & $\begin{array}{l}\text { Australia } \\
\text { (Quest) }\end{array}$ & $\begin{array}{l}\text { Shareholders } \\
\text { Stockbrokers } \\
\text { Accounting } \\
\text { academics } \\
\text { Financial inst } \\
\text { Review org. } \\
\text { Total } \\
\text { (primary stk) }\end{array}$ & $\begin{array}{l}254 \\
93 \\
63 \\
24 \\
40 \\
474\end{array}$ & $\begin{array}{l}60 \\
16 \\
24 \\
6 \\
12 \\
118\end{array}$ & $\begin{array}{l}23.6 \% \\
17.2 \% \\
38.1 \% \\
25.0 \% \\
30.0 \% \\
24.9 \%\end{array}$ & $\begin{array}{l}\text { Environmental information is } \\
\text { generally considered relevant to } \\
\text { influence decisions, except to the } \\
\text { group of stockbrokers and } \\
\text { research analysts who } \\
\text { underestimate its value. The } \\
\text { annual report is an important } \\
\text { information point. }\end{array}$ \\
\hline $\begin{array}{l}\text { O’Dwy } \\
\text { er } \\
(2002)\end{array}$ & $\begin{array}{l}\text { Irish } \\
\text { (Interv) }\end{array}$ & $\begin{array}{l}\text { Managers of } \\
\text { Irish public } \\
\text { limited } \\
\text { companies } \\
\text { (primary stk) }\end{array}$ & 29 & 29 & $100 \%$ & $\begin{array}{l}\text { The environmental information is } \\
\text { provided mainly as a consequence } \\
\text { of public pressure. Many } \\
\text { companies do not invest efforts to } \\
\text { produce the CSD because it is not } \\
\text { credible in an Irish context. They } \\
\text { call for the existence of a specific } \\
\text { regulation. }\end{array}$ \\
\hline $\begin{array}{l}\text { Al- } \\
\text { Khater } \\
\& \\
\text { Naser } \\
(2003)\end{array}$ & $\begin{array}{l}\text { Qatar } \\
\text { (Quest) }\end{array}$ & $\begin{array}{l}\text { Accountants } \\
\text { External } \\
\text { audit } \\
\text { Academician } \\
\text { s } \\
\text { Bank officer } \\
\text { Total } \\
\text { (secondary } \\
\text { stk) }\end{array}$ & $\begin{array}{l}100 \\
30 \\
30 \\
100 \\
260\end{array}$ & $\begin{array}{l}58 \\
18 \\
18 \\
49 \\
143\end{array}$ & $\begin{array}{l}58 \% \\
60 \% \\
60 \% \\
49 \% \\
55 \%\end{array}$ & $\begin{array}{l}\text { The target audiences of corporate } \\
\text { reporting information are } \\
\text { shareholders, investors, and } \\
\text { creditors. However, other groups } \\
\text { should be included in the target } \\
\text { audience: management, } \\
\text { employees, and customers. The } \\
\text { respondents prefer that the } \\
\text { information disclosed in annual } \\
\text { reports include descriptive, }\end{array}$ \\
\hline
\end{tabular}




\begin{tabular}{|c|c|c|c|c|c|c|}
\hline & & & & & & $\begin{array}{l}\text { quantitative, and monetary } \\
\text { methods. }\end{array}$ \\
\hline $\begin{array}{l}\text { O’Dwy } \\
\text { er } \\
(2005)\end{array}$ & $\begin{array}{l}\text { Irish } \\
\text { (Interv) }\end{array}$ & $\begin{array}{l}\text { NGO leaders } \\
\text { (secondary } \\
\text { stk) }\end{array}$ & 8 & 8 & $100 \%$ & $\begin{array}{l}\text { The NGOs' leaders call for the } \\
\text { existence of a specific regulation } \\
\text { or legal mechanism (law) which } \\
\text { would force companies to } \\
\text { improve voluntary disclosures and } \\
\text { pay more attention to } \\
\text { environmental performance. }\end{array}$ \\
\hline $\begin{array}{l}\text { Solom } \\
\text { on \& } \\
\text { Solom } \\
\text { on } \\
(2006)\end{array}$ & $\begin{array}{l}\text { UK } \\
\text { (Interv) }\end{array}$ & $\begin{array}{l}\text { Institutional } \\
\text { investment } \\
\text { community } \\
\text { (primary stk) }\end{array}$ & 21 & 21 & $100 \%$ & $\begin{array}{l}\text { Institutional investors are } \\
\text { dissatisfied with the quantity and } \\
\text { quality of public disclosure in } \\
\text { SEE, concluding that the } \\
\text { information is inadequate for their } \\
\text { portfolio investment decisions. } \\
\text { The researchers evidenced a } \\
\text { strong bi-directional channel } \\
\text { among private and public SEE } \\
\text { disclosure. }\end{array}$ \\
\hline $\begin{array}{l}\text { Villier } \\
\& \text { van } \\
\text { Staden } \\
(2010)\end{array}$ & $\begin{array}{l}\text { US } \\
\text { UK } \\
\text { Australia } \\
\text { (Quest) }\end{array}$ & $\begin{array}{l}\text { US } \\
\text { UK } \\
\text { Australia } \\
\text { Total } \\
\text { (primary stk) }\end{array}$ & $\begin{array}{l}500 \\
523 \\
1473 \\
2496\end{array}$ & $\begin{array}{l}64 \\
105 \\
305 \\
474\end{array}$ & $\begin{array}{l}12.8 \% \\
20.1 \% \\
20.7 \% \\
19.0 \%\end{array}$ & $\begin{array}{l}\text { Some differences were observed } \\
\text { between the US, UK, and } \\
\text { Australia, but in general, the } \\
\text { shareholders prefer reports that } \\
\text { have been audited in order to } \\
\text { reduce the asymmetry of } \\
\text { information. Age and retirement } \\
\text { status did not influence } \\
\text { shareholders' views regarding } \\
\text { environmental disclosure. }\end{array}$ \\
\hline
\end{tabular}

Note: $*$ Quest $=$ questionnaire and Interv $=$ interview 
Table 2. Demand, Preferred Medium, and Method Used to Disclose Social Reports.

\begin{tabular}{|c|c|c|c|c|}
\hline & Mean & $\begin{array}{l}\text { Std. } \\
\text { Deviation }\end{array}$ & $\begin{array}{l}\% \text { agree } \\
\text { and } \\
\text { strongly } \\
\text { agree }\end{array}$ & $\begin{array}{l}\% \text { disagree } \\
\text { and } \\
\text { strongly } \\
\text { disagree }\end{array}$ \\
\hline \multicolumn{5}{|l|}{ Demand for social reporting } \\
\hline $\begin{array}{l}\text { Social reports documents should follow standard } \\
\text { internationally-accepted models. }\end{array}$ & 4.15 & 0.79 & 81.50 & 2.60 \\
\hline $\begin{array}{l}\text { Social reports should be mandatory for all the } \\
\text { cooperative banks in Trentino. }\end{array}$ & 4.05 & 0.84 & 74.00 & 3.00 \\
\hline $\begin{array}{l}\text { I would like the cooperative banks in Trentino to adopt } \\
\text { social reporting tools. }\end{array}$ & 3.93 & 0.79 & 72.80 & 2.50 \\
\hline \multicolumn{5}{|c|}{ Most effective medium to disseminate social and environmental information } \\
\hline A separate document, for instance a social report & 3.78 & 1.02 & 68.50 & 11.60 \\
\hline Inside the company's annual report & 3.61 & 1.07 & 62.10 & 14.50 \\
\hline The company's website & 3.53 & 1.28 & 59.80 & 20.60 \\
\hline $\begin{array}{l}\text { Other means, such as brochures, newspaper articles, } \\
\text { magazines, newsletters, and other media }\end{array}$ & 2.68 & 1.26 & 29.00 & 43.80 \\
\hline \multicolumn{5}{|l|}{$\begin{array}{l}\text { Methods used to disclose social and environmental } \\
\text { information }\end{array}$} \\
\hline $\begin{array}{l}\text { A printed document (narrative/descriptive) that can be } \\
\text { easily read and understood }\end{array}$ & 4.07 & 0.98 & 80.90 & 9.10 \\
\hline $\begin{array}{l}\text { A printed technical document that measures the } \\
\text { company's environmental and social performance }\end{array}$ & 3.28 & 1.11 & 48.20 & 20.70 \\
\hline $\begin{array}{l}\text { A simple printed document (brochure) full of charts, } \\
\text { graphs, and images }\end{array}$ & 3.12 & 1.23 & 44.50 & 31.30 \\
\hline $\begin{array}{l}\text { An electronic tool (web page, twitter, or blog) without } \\
\text { the support of printed documents }\end{array}$ & 2.70 & 1.35 & 30.70 & 47.30 \\
\hline
\end{tabular}


Table 3. Members' Motivation for Receiving Social Reports.

\begin{tabular}{|l|l|l|l|l|}
\hline & Mean & $\begin{array}{l}\text { Std. } \\
\text { Deviation }\end{array}$ & $\begin{array}{l}\% \text { agree } \\
\text { and } \\
\text { strongly } \\
\text { agree }\end{array}$ & $\begin{array}{l}\% \text { disagree } \\
\text { and } \\
\text { strongly } \\
\text { disagree }\end{array}$ \\
\hline $\begin{array}{l}\text { I would like to receive information on the activities } \\
\text { carried out on behalf of shareholders and of the } \\
\text { local community. }\end{array}$ & 4.17 & 0.66 & 86.40 & 13.60 \\
\hline $\begin{array}{l}\text { I would like information on the commitment of } \\
\text { cooperative banks in conducting a socially- } \\
\text { responsible business. }\end{array}$ & 4.17 & 0.76 & 84.60 & 2.00 \\
\hline Because it is the right thing to do. & 4.16 & 0.80 & 82.30 & 2.70 \\
\hline $\begin{array}{l}\text { I would like to verify that the disclosed information } \\
\text { is actually in line with the bank's behavior. }\end{array}$ & 3.99 & 0.78 & 77.30 & 2.70 \\
\hline $\begin{array}{l}\text { I would like to understand how the cooperative } \\
\text { bank uses its economic resources. }\end{array}$ & 3.98 & 0.88 & 73.80 & 4.30 \\
\hline $\begin{array}{l}\text { I believe that CBs are by definition socially } \\
\text { responsible, and therefore, should prepare a report. }\end{array}$ & 3.94 & 0.85 & 75.40 & 4.20 \\
\hline $\begin{array}{l}\text { I would like to verify that the cooperative banks } \\
\text { comply with the law regarding environmental and } \\
\text { social practices. }\end{array}$ & 3.75 & 0.90 & 64.70 & 6.90 \\
\hline I would like to learn more about CBs. & 3.53 & 0.94 & 55.70 & 12.50 \\
\hline
\end{tabular}


Table 4. Verification of Social and Environmental Reports.

\begin{tabular}{|c|c|c|c|c|}
\hline Demand for verification & Mean & $\begin{array}{l}\text { Std. } \\
\text { Deviatio } \\
n\end{array}$ & $\begin{array}{l}\% \quad \text { agree } \\
\text { and } \\
\text { strongly } \\
\text { agree } \\
\end{array}$ & $\begin{array}{ll}\% & \text { disagree } \\
\text { and } & \text { strongly } \\
\text { disagree }\end{array}$ \\
\hline $\begin{array}{l}\text { The social reports should be verified by independent } \\
\text { bodies external to this bank. }\end{array}$ & 3.89 & 1.09 & 72.40 & 16.70 \\
\hline $\begin{array}{l}\text { The social reports should be verified by a working } \\
\text { group within the company. }\end{array}$ & 3.28 & 1.24 & 48.20 & 26.60 \\
\hline $\begin{array}{l}\text { The social reports should not be verified because the } \\
\text { people who prepare it do so in good faith. }\end{array}$ & 2.06 & 1.15 & 12.70 & 67.00 \\
\hline $\begin{array}{l}\text { The social reports do not require any verification } \\
\text { procedures, internal or external. }\end{array}$ & 1.99 & 1.13 & 10.70 & 70.20 \\
\hline The social reports have no need to be verified. & 1.87 & 1.11 & 10.20 & 76.60 \\
\hline \multicolumn{5}{|l|}{ Preferred verifiers } \\
\hline $\begin{array}{l}\text { An independent expert auditor on social report } \\
\text { documentation }\end{array}$ & 3.76 & 1.20 & 70.10 & 16.20 \\
\hline An independent expert auditor of annual reports & 3.45 & 1.26 & 56.50 & 24.16 \\
\hline An external body (i.e. Cooperative Bank Federation) & 3.15 & 1.30 & 45.80 & 31.60 \\
\hline A working group within the cooperative bank & 2.88 & 1.32 & 36.90 & 39.00 \\
\hline An internal consultant of the cooperative bank & 2.54 & 1.25 & 24.10 & 51.30 \\
\hline
\end{tabular}


Table 5. Satisfaction Level with the Current Social Report of the CB under Investigation.

\begin{tabular}{|l|l|l|l|l|l|}
\hline & $\begin{array}{l}\text { Completely } \\
\text { dissatisfied }\end{array}$ & Dissatisfied & $\begin{array}{l}\text { Neither satisfied } \\
\text { nor dissatisfied }\end{array}$ & Satisfied & $\begin{array}{l}\text { Completely } \\
\text { satisfied }\end{array}$ \\
\hline $\begin{array}{l}\text { General } \\
\text { opinion }\end{array}$ & $0 \%$ & $2 \%$ & $11 \%$ & $73 \%$ & $14 \%$ \\
\hline
\end{tabular}


Table 6. Assessment of Social Report.

\begin{tabular}{|l|l|l|l|l|}
\hline & Mean & $\begin{array}{l}\text { Std. } \\
\text { Deviation }\end{array}$ & $\begin{array}{l}\text { \% agree and } \\
\text { strongly } \\
\text { agree }\end{array}$ & $\begin{array}{l}\text { disagree } \\
\text { and strongly } \\
\text { disagree }\end{array}$ \\
\hline is useful. & 4.25 & 0.68 & 93.1 & 2.00 \\
\hline is credible. & 4.08 & 0.73 & 84.9 & 2.40 \\
\hline is transparent. & 3.98 & 0.75 & 78.7 & 3.00 \\
\hline is complete. & 3.88 & 0.87 & 72.9 & 5.80 \\
\hline $\begin{array}{l}\text { is a document that presents in detail the social } \\
\text { and environmental impact of all activities } \\
\text { carried out by this cooperative bank. }\end{array}$ & 3.81 & 0.81 & 74.9 & 6.60 \\
\hline is easy to read. & 3.79 & 0.88 & 67.5 & 5.70 \\
\hline is a public relations document. & 3.66 & 0.77 & 63.5 & 6.10 \\
\hline is comparable over time. & 3.64 & 0.75 & 60.6 & 4.60 \\
\hline contains information relevant to all stakeholders. & 3.54 & 0.85 & 53.2 & 8.40 \\
\hline
\end{tabular}


Table 7. Perceived Corporate Motives for Disclosure Social Report.

\begin{tabular}{|l|l|l|l|l|}
\hline $\begin{array}{l}\text { Do you think that this CB prepares social report to } \\
\text {.. }\end{array}$ & Mean & $\begin{array}{l}\text { Std. } \\
\text { Deviation }\end{array}$ & $\begin{array}{l}\text { \% agree and } \\
\text { strongly } \\
\text { agree }\end{array}$ & $\begin{array}{l}\text { disagree } \\
\text { and strongly } \\
\text { disagree }\end{array}$ \\
\hline $\begin{array}{l}\text { communicate to members the activities of the } \\
\text { cooperative bank during the course of the year }\end{array}$ & 4.13 & 0.76 & 88.50 & 4.50 \\
\hline build trust among members by improving relations & 4.01 & 0.87 & 82.10 & 3.10 \\
\hline be transparent to the community & 3.97 & 0.83 & 78.40 & 3.40 \\
\hline because it feels morally right to do so & 3.65 & 1.04 & 62.10 & 12.10 \\
\hline contribute to sustainable development & 3.54 & 0.96 & 62.80 & 11.50 \\
\hline $\begin{array}{l}\text { demonstrate to various stakeholders the social and } \\
\text { environmental impact of the activities of the co- } \\
\text { operative bank }\end{array}$ & 3.24 & 0.98 & 45.10 & 17.90 \\
\hline promote themselves and improve their image & 2.99 & 1.12 & 37.90 & 30.20 \\
\hline $\begin{array}{l}\text { respond to political pressure for improved } \\
\text { transparency }\end{array}$ & 2.75 & 1.04 & 23.60 & 39.00 \\
\hline prevent possible new regulations in the future & 2.74 & 1.13 & 26.20 & 40.50 \\
\hline $\begin{array}{l}\text { divert attention from irresponsible business } \\
\text { practices }\end{array}$ & 2.48 & 1.22 & 22.10 & 53.70 \\
\hline $\begin{array}{l}\text { imitate other cooperative banks that do social } \\
\text { reporting }\end{array}$ & 2.46 & 1.19 & 18.80 & 54.60 \\
\hline $\begin{array}{l}\text { make an economic return (for their own personal } \\
\text { gain) }\end{array}$ & 2.45 & 1.09 & 17.50 & 53.10 \\
\hline $\begin{array}{l}\text { take into account pressure received from members } \\
\text { or other stakeholders }\end{array}$ & 2.35 & 1.07 & 14.60 & 57.30 \\
\hline
\end{tabular}


Table 8. Longitudinal content analysis: number of sentences (1999-2011).

\begin{tabular}{|l|r|r|r|r|r|r|r|r|r|r|r|r|r|r|}
\hline STAKEHOLDE & 199 & 200 & 200 & 200 & 200 & 200 & 200 & 200 & 200 & 200 & 200 & 201 & 201 & \\
R & 9 & 0 & 1 & 2 & 3 & 4 & 5 & 6 & 7 & 8 & 9 & 0 & 1 & Total \\
\hline MEMBERS & 27 & 50 & 40 & 65 & 63 & 86 & 53 & 51 & 102 & 79 & 62 & 70 & 52 & $\mathbf{8 0 0}$ \\
\hline CUSTOMERS & 4 & 15 & 6 & 13 & 24 & 19 & 38 & 17 & 55 & 36 & 66 & 64 & 57 & $\mathbf{4 1 4}$ \\
\hline SUPPLIER & 2 & 5 & 7 & 3 & 0 & 0 & 0 & 0 & 0 & 0 & 6 & 12 & 13 & $\mathbf{4 8}$ \\
\hline COMMUNITY & 5 & 12 & 18 & 31 & 16 & 28 & 76 & 75 & 51 & 75 & 118 & 186 & 78 & $\mathbf{7 6 9}$ \\
\hline EMPLOYEES & 11 & 12 & 18 & 8 & 11 & 20 & 33 & 54 & 63 & 42 & 102 & 98 & 38 & $\mathbf{5 1 0}$ \\
\hline & & & & & & & & & & & & & & $\mathbf{2 , 5 4}$ \\
Total & $\mathbf{4 9}$ & $\mathbf{9 4}$ & $\mathbf{8 9}$ & $\mathbf{1 2 0}$ & $\mathbf{1 1 4}$ & $\mathbf{1 5 3}$ & $\mathbf{2 0 0}$ & $\mathbf{1 9 7}$ & $\mathbf{2 7 1}$ & $\mathbf{2 3 2}$ & $\mathbf{3 5 4}$ & $\mathbf{4 3 0}$ & $\mathbf{2 3 8}$ & $\mathbf{1}$ \\
\hline
\end{tabular}

